\title{
Beyond Defence: City Fortifications and Urban Identity in Levoča
}

\author{
Martina MRÁZOVÁ
}

\begin{abstract}
Urban identity, or the genius loci of a town is a concept that has evolved throughout history and is determined by various aspects of the city and its architecture. On the example of the city walls in Levoča, this study discusses how city walls contribute to the creation and preservation of a distinctive urban identity of a historic town. The discussion consists primarily of three aspects - the function of city walls, their representation in visual sources and their conservation and reconstruction. On the example of the Košice Gate in Levoča, it will be argued that by conserving city fortifications, we are able to preserve the unique character and the identity of the town. Overall it will be argued that the Levoča fortification system, although not completely preserved, has contributed to the creation and preservation of the town's unique identity.
\end{abstract}

Keywords: City walls, Fortifications, Levoča, Urban identity, Conservation

\section{Introduction}

City walls played an important role in the history of many European towns since the Middle Ages, being the symbol of civitas, an area of security, law and order. ${ }^{1}$ The importance of city fortifications was also expressed by the Renaissance scholar Leon Battista Alberti, as according to him, any town without a wall was considered naked. ${ }^{2}$ It was not only this physical importance of fortifications, but also the fact that they "have always played a critical role in shaping the identities and images of the communities they embrace". ${ }^{3}$ In this instance, the term 'identity' can be understood and interpreted in various ways, such as the central basis of the social structure combined with memory and ideology. ${ }^{4}$ In the context of

1 JÜTTE, D.: Entering a City: On a lost Early Modern Practice. In: Urban History, 41, 2014, no. 2, p. 205.

2 CREIGHTON, O.: Contested Townscapes: The Walled City as World Heritage. In: World Archaeology, 39, 2007, no. 3, p. 344.

3 BRUCE, D. - CREIGHTON, O.: Contested Identities: The Dissonant Heritage of European Town Walls and Walled architecture and urbanism, we are referring to "the reflection of the historical context of the city as a part of both its physical components and cultural spirit". ${ }^{5}$ There are many factors that can shape the identity of the town, whether it is buildings, their conservation and reconstruction, or simply the visual appearance of the town.

Using the city walls of Levoča (Fig. 1), as our case study, this paper will explore how a fortification system can contribute to the creation and preservation of a unique identity of a town and its dwellers. Firstly, this study will seek to explain how the function of the city walls has changed over centuries, from defensive in the past, to a more symbolic in the present. Secondly, it will discuss why the image of a city and its visual representations are essential in

Towns. In: International Journal of Heritage Studies, 2006, p. 1.

4 Medieval Urban Identity: Health, Economy and Regulation. Ed.: SABATE, F. Newcastle upon Tyne 2015, p. 3.

5 ELEWA, A.: Conserving Historical Areas through the Roles of Main Cities: Urban Identity in the Era of Globalisation. In: Cities' Identity through Architecture and Arts. London 2018, p. 473. 
the process of creation of its identity. This section will firstly look at historical visual representations such as seals and paintings and later on it will compare them to the representation of the town in the present, what will lead to a debate about whether city walls act as a symbol of the town or a brand. Consequently, this will lead to a discussion about what impact can preservation and reconstruction of city walls have on the identity of the city. Additionally, a discussion of the future use of city walls will follow. The first two sections will be examined firstly from historical and then from the contemporary point of view. It will be argued that fortification systems are an important element in the formation of a unique identity of a city.

\section{Historical context}

The historic town of Levoča, situated in the northeast of Slovakia in the region of Spiš, today belongs to one of the few towns with preserved city walls in Central Europe. The history of Levoča's fortification system dates back to the first half of the 13th century, when after the Mongol invasion, the Kingdom of Hungary needed renewal. It was essential for the king Béla IV to reconsider the question of defence against another possible Mongol invasion and any future threats. Since reconstruction of the conquered land was a crucial mission, the king was forced not only to give the Hungarian feudal lords more freedom on their estates, but also to invite German settlers - the (Spiš) Saxons to rebuild the destroyed towns. This was the case of Levoča, historically mentioned for the first time in 1249.6 As a free royal town, Levoča had the right and the duty to build a strong fortification system, which caused a lot of conflict and rivalry with other towns in the region of Spiš that were denied this possibility. ${ }^{7}$ The beginnings of the fortifications' construction have not yet been properly explained, mainly due to

\footnotetext{
${ }^{6}$ BARTA, I. (Ed. Ervin Pamlényi): A History of Hungary. London, 1975, p. 63.

SUCHÝ, M.: Dejiny Levoře 1. Košice 1974, p. 95.

8 JACKOVÁ, A. - ODLER, P.: Pamiatkový fond lokality svetového dedičstva UNESCO Levoča, Spišský hrad a pamiatky okolia. In: Monumentorum Tutela, 23, 2010, p. 52.
}

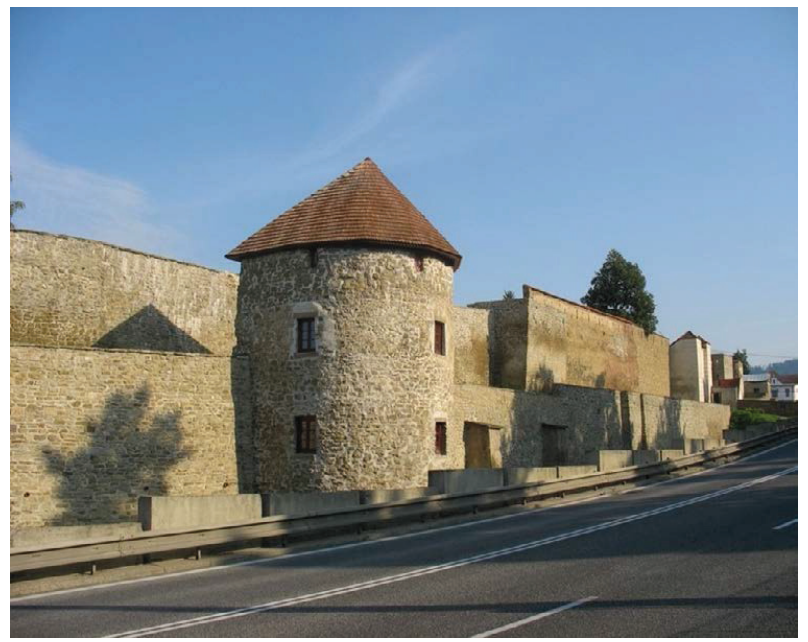

Fig. 1: Levoča city fortifications, view from the east. Photo: Levoča Information Office.

the fire which destroyed the city archive containing several relevant documents in $1550 .^{8}$ Numerous historians would date the construction of the walls to the end of the 13th century, due to the collective privilege of the Community of Spiš Saxons, an autonomous province in the region of Spiš, in which Levoča gained the leading position. ${ }^{9}$ However, it is essential to note that the privilege does not mention any right to fortify the city with walls. Some claim that the seal of the Community of Spiš Saxons showing a fortress is a proof of the walls' existence (Fig. 2.). However, this statement has been questioned by many historians, since there is lack of supporting evidence. ${ }^{10}$ According to Rábik, by the end of the 13 th century there were only eight urban settlements surrounded by city walls on the territory of the present-day Slovakia, among them Levoča, Bratislava, Banská Štiavnica, Nitra, Trnava, Košice and Podolínec. ${ }^{11}$ On the other hand, architect Menclová claims that Levoča was fortified during the first half of the 14th century. Despite some disagreements among

9 JANOVSKÁ, M. - OLEJNÍK, V.: Príspevok k budovaniu opevnení po mongolskom vpáde na Spiši. In: Archaeologia Historica, 40, 2015, no. 2, p. 632.

${ }^{10}$ JACKOVÁ - ODLER 2010 (see in note 8), p. 52.

${ }^{11}$ RÁBIK, V.: Mestské hradby vo svetle stredovekých písomných prameňov. In: Monumentorum Tutela, 16, 2005, p. 208. 


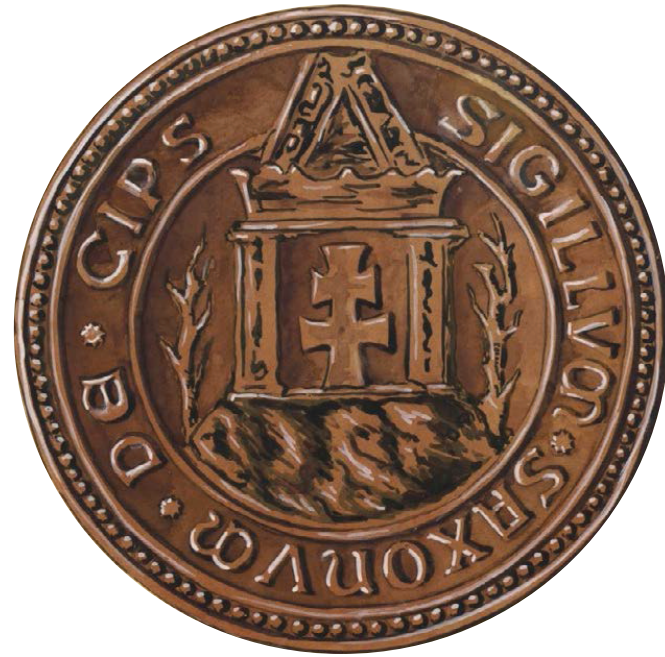

Fig. 2: Seal of the Community of Spis Saxons. Tempera on paper, $33 \times 45$ cm. Photo: Slovak National Museum.

historians about the exact date of the fortifications' construction, it is safe to claim that the city was fully fortified by the end of the 14th century. ${ }^{12}$ Although we are unable to study the development of the fortification system throughout the centuries in more detail, we are aware of some construction interventions of the walls that were mainly of destructive character. ${ }^{13}$ The year 1763 is very important for the city and the fortification system, as at that time Levoča lost its function as a military fortress. ${ }^{14}$ Another example of a big change was the construction of the military barracks in the 1880s. For this purpose, the Lower Gate was demolished in the second half of the 19th century, as well as some parts of the walls that hindered the construction sites. ${ }^{15}$ It was only

\footnotetext{
${ }^{12}$ LUKÁČ, G.: Vývoj mestského opevnenia v Levoči. Lecture: International Conference of Medieval Archaeologists, Pardubice, Czech Republic, October 24, 2009.

${ }^{13}$ SUCHÝ 1974 (see in note 7), p. 96.

${ }^{14}$ JACKOVÁ, A. - LUKÁČ, G. - SEMANOVÁ, E. - TOPORCEROVÁ, E. (Krajský pamiatkový úrad Prešov - pracovisko Levoča): Pamiatková rezervácia Levoća, zásady ochrany, obnovy a prežentácie hodnôt pamiatkového územia. Levoča 2006-2007, p. 27.

${ }^{15}$ CHALUPECKÝ, I.: Dejiny Levoče 2. Košice 1975, p. 148.
}

at the beginning of the 20th century when the city fortifications began to be recognised and valued as a historical monument. They were brought to the attention of the conservation authorities, but that did not stop the city from selling some of their parts to private citizens. ${ }^{16}$ According to Chalupecký, thanks to the conservatism of the citizens, the major part of the city walls is still standing today. ${ }^{17} \mathrm{It}$ was also due to lack of urban and social evolution of the city over the last two centuries, that the fortification system has been well preserved. ${ }^{18}$ The city walls of Levoča, surrounding the historic town are one of the best-preserved fortification complexes in Slovakia. In comparison with other towns of the country, where only parts of the fortification systems are conserved, the Levoča city fortification complex is the most extensive, with an extent of $80 \%$ of preserved walls in the whole profile, which equals 1.8 kilometres in length. ${ }^{19}$ The fortification complex offers a fertile scope for discussion not only about the impact on the city's identity, but it also raises questions about authenticity from architectural and art-historical points of view.

\section{Function as Meaning}

According to architect Kim Dovey, "The question is not whether architecture constructs identities and stabilizes meanings, but how and in whose interests" ${ }^{20}$ Thus, there is no doubt that architectural structures are built to fulfil certain functions and meanings. In purely utilitarian terms, the function of a building can be seen as a synonym to its intended use, destination or purpose. ${ }^{21}$ When talking about fortifications, their functions can be various - prag-

\footnotetext{
${ }^{16}$ Ibidem, pp. 182-183.

${ }^{17}$ Ibidem, p. 144.

${ }^{18}$ SUCHÝ 1974 (see in note 7), p. 96.

${ }^{19}$ Ibidem, p. 96.

${ }^{20}$ DOVEY, K.: Becoming Places: Urbanism/Architecture/ Identity/ Power. London 2009, p. 45.

${ }^{21}$ PALYVOU, C.: On Function in Architecture and Archaeology. In: Daidalos at Work: A Phenomenological Approach to the Study of Minoan Architecture. Philadelphia 2018, p. 172.
} 
matic, symbolic or urban. Certainly, the first function of city walls that comes to mind is the defensive, which can be considered as the original and in many cases the most important one. ${ }^{22}$ However, the term function does not always refer only to the practical use, but it generally includes the social or symbolic purposes of buildings which are often ignored. ${ }^{23}$ In this section, it will be argued that functions of architectural structures such as city walls change over time and can have a considerable impact on their meaning and the identity of the town.

If we consider the main function of city walls as simply pragmatic, their meaning is thus determined from a purely architectural viewpoint as systems of defence. Therefore, the meaning of city walls and how people see them can be determined by their function. A walled city can be primarily seen as a place of refuge for its inhabitants, as since the Middle Ages, the crucial pragmatic function of city fortifications was to defend. ${ }^{24}$ In most cases walls served to protect not only the city or the region, but they contributed to the defensive system of the country as a whole. ${ }^{25}$ This only shows the importance of such walled towns in the context of bigger social structures. Since this study focuses on the town of Levoča, it is essential to note that the mere possession of city walls was a distinctive feature that characterised a free royal town in the Kingdom of Hungary and differentiated it from others. Although many of them were considered as safe places of refuge, it would be wrong to describe them as impregnable. This can be seen in the example of Levoča, which was conquered a couple of times, for instance in 1431 by the Hussites. ${ }^{26}$ Thus, walls and their defensive function contributed to the creation of a unique identity of a city, reinforcing its

\footnotetext{
${ }^{22}$ MÜTH, S.: Functions and Semantics of Fortifications: An Introduction. In: Focus on Fortifications: New Research on Fortifications in the Ancient Mediterranean and the Near East. Oxford 2016, p. 183.

${ }^{23}$ PALYVOU 2009 (see in note 21), p. 173.

${ }^{24}$ City Walls: The Urban Enceinte in Global Perspective. Ed.: TRACY, J. Cambridge 2009, p. 88.

${ }^{25}$ RÁBIK, V. - LABANC, P. - TIBENSKÝ, M.: Vývoj stredovekých miest na Slovensku I. Trnava 2013, p. 58; CREIGHTON,
}

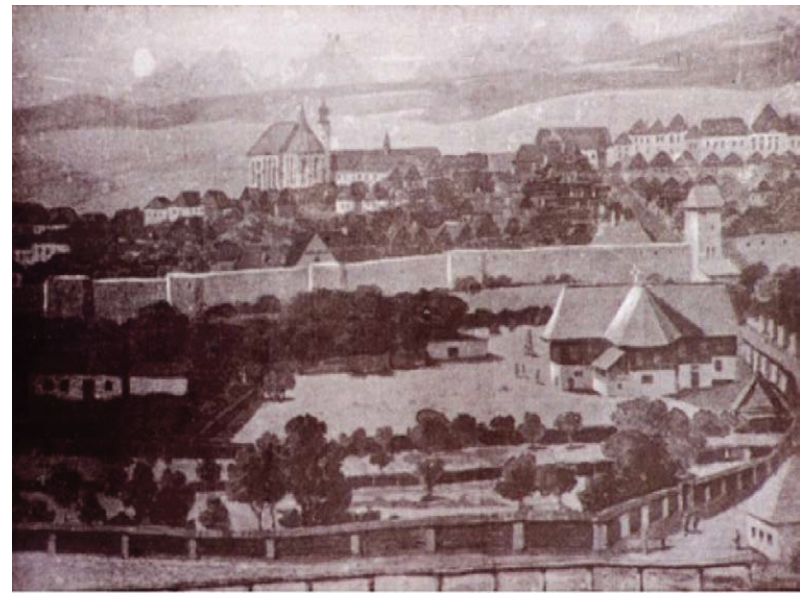

Fig. 3: Detail of a painting of Levoća. Author and date unknown. Photo: Levoča Information Office.

character of a free royal town and a place of refuge for its inhabitants.

Secondly, it is commonly perceived that another pragmatic function of city walls was to unite citizens, since they physically surrounded the inhabitants of the town - people of different backgrounds, classes or religious beliefs. ${ }^{27}$ Social and class divisions were very common within these walled structures. Our case study well illustrates this point. From a political and legal point of view there were two groups of people living in Levoča - those who possessed the rights of citizens and those who did not. ${ }^{28}$ The city planning accordingly mirrored these divisions very accurately. It was a general rule that wealthy burghers lived on the square, merchants in lateral streets, poorer citizens farther away from the city centre closer to the town walls and beyond the walls lived the homeless. ${ }^{29}$

O. - HIGHAM, R.: Medieval Town Walls, An Archaeology and Social History of Urban Defence. Stroud 2005, p. 166.

${ }^{26}$ COLLECTIVE OF AUTHORS: Levoča: národná kultúrna pamiatka. Bratislava 2017, p. 19.

${ }^{27}$ CREIGHTON 2007 (see in note 2), p. 346.

${ }^{28}$ SUCHÝ 1974 (see in note 7), p. 277.

${ }^{29}$ LUKÁČ, G.: Stredoveký kláštor minoritov v Levoči. Predbežné výsledky archeologického výskumu v rokoch 1992-1996. In: Z minulosti Spiša V-VI 1997/1998, 1999, p. 64. 
In addition to these social divisions, in some cases, city walls also contributed to religious segregation within the city. According to the religious law made by the King Leopold I at the Diet of Sopron in 1681, "protestants were allowed churches only in free, royal towns, which were to be built on the outskirts, outside town walls". ${ }^{30}$ In the region of Spiš, formerly part of the Kingdom of Hungary, Protestants were permitted to build a specific type of churches, called 'wooden articular churches' outside the city walls, which was also the case of Levoča (Fig. 3). ${ }^{31}$ Similar religious divisions could be seen in other walled towns, such as Bardejov or Cracow, where Jewish districts could be built only outside the city walls. ${ }^{32}$ Although inhabitants of a walled city were, thanks to its walls, perceived as a unit from the outside, the situation inside them was completely different. Hence city walls, although physically uniting citizens, acted as a method of creating divisions within certain communities, whether of religious or class character. ${ }^{33}$ Therefore, the function of city walls of uniting and dividing the inhabitants of the city contributed to the creation of its unique identity in terms of physically uniting people from different ethnocultural and religious backgrounds, while creating social differences among them.

Furthermore, over time, the defensive function of city walls vanished, and, in many cases, they acquired a new purpose following some changes of the geopolitical situation in Europe during the $18^{\text {th }}$ century. Such changes of function can have a great impact on the meaning and on the values fortifications were meant to represent. During the $18^{\text {th }}$ century, city walls across Europe permanently

\footnotetext{
${ }^{30}$ SPIESZ, A. - ČAPLOVIČ, D.: Illustrated Slovak History: A Struggle for Sovereignty in Central Europe. Wauconda 2006, p. 77.

${ }^{31}$ PAULUSOVÁ, S.: Artikulárne kostoly. In: Pamiatky a múzeá, no. 4, 1995, pp. 50-55.

${ }^{32}$ CREIGHTON 2007 (see in note 2), p. 347.

${ }^{33}$ Ibidem, p. 344.

${ }^{34}$ KRAJNIK, D. - PETROVIĆ KRAJNIK, L.: Models of Bastion Fortifications Integration in Cities. In: Cultural Urban Heritage: Development, Learning and Landscape Strate-
}

lost their defensive function and began to present an obstacle to urban and social development of the city, which was also the case of Levoča. ${ }^{34}$ There was no need for their maintenance anymore, since they were no longer seen as a necessity for the town and its defence. The walls - a symbol of power and security for many centuries, became an obstacle for the city and its urban and social development. In this new socio-historical context, two alternatives evolved in the process of dealing with fortifications. The first one is an example of walled towns which have undergone "a functional and morphological transformation of spaces at the place of bastion fortifications". ${ }^{35}$ In other words, in these towns, fortification systems were replaced with new urban structures such as roads. Therefore, not only did the walls lose their function, but they themselves were torn down or rebuilt. In Vienna, the traces of the former city walls "have marked the city with a distinctive feature," the Ringstrasse, which "had become a paradigmatic example and had greatly influenced the formation of the European city of the $19^{\text {th }}$ century". ${ }^{36}$ Another example is the Italian city Mantua, where the ring of streets replaced the former fortifications, while still allowing to trace the historic gates. ${ }^{37}$ Therefore the loss of function of city walls not only altered the visual appearance of the city, such as in Vienna, but it also changed its character. The city lost its emblem - the walls, and thus became known for another distinctive feature - the Ringstrasse. Consequently, these changes in urban layout of such cities completely altered their identities of former walled towns. The second example shows cities in which fortification systems have

gies. Eds.: OBAD SCITAROCI, M. - BOJANIĆ OBAD SĆITAROCI, B. - MRDA, A. Springer 2019, p. 409; JACKOVÁ - LUKÁČ - SEMANOVÁ - TOPORCEROVÁ 2006-2007 (see in note 14), p. 27.

${ }^{35}$ KRAJNIK - PETROVIĆ KRAJNIK 2019 (see in note 34), p. 410

${ }^{36}$ HIRST, P.: The Defence of Places: Fortifications as Architecture [part 1]. In: $A A$ Files, no. 33, 1997, p. 13; KRAJNIK PETROVIĆ KRAJNIK 2019 (see in note 34), p. 410.

${ }^{37}$ INTERNATIONAL COUNCIL ON MONUMENTS AND SITES, World Heritage Committee. Québec 2008, p. 175. 
undergone smaller alterations. Nevertheless, such changes can also completely alter the character and identity of a city. Examples of Levoča, Dubrovnik or the Italian cities Lucca and Palmanova are cases where "the transformation of fortifications has not been carried out," and the defence complex is still clearly readable in the present urban layout. ${ }^{38}$ In these towns, the walled structures were preserved albeit not in their entirety. Fortifications in such towns were not completely rebuilt or torn down, but instead were given a new public function. Krajnik develops this point by stating, "the preserved military buildings were given civil use, and the fortification belt was given the function of urban public space". ${ }^{39}$ He later continues by saying that this example "implied smaller interventions in urban planning and architectural sense, while the emphasis was on finding a way of maintaining the buildings". ${ }^{40}$ This concept can be also seen in European walled towns such as Brno or Osijek, where parks and boulevards were created "as a part of transformation of fortifications". ${ }^{41}$

In Levoča, it was the local Beautification Association which significantly influenced the structure of the city and the appearance of its fortifications with the aim to aesthetically change the city and its surroundings in the 1880s. Part of the changes was also construction of parks and promenades around the walls. ${ }^{42}$ This "beautification" was carried out primarily on the western part of the walls, where a public park, Schiessplatz ("shooting range") was created (Fig. 4). An area originally used to defend the city against external enemies, in the $19^{\text {th }}$ century acquired a new function as a green public park. ${ }^{43}$ Thanks to the fact that these places were assigned new functions without a need for any extensive alterations, the city walls remained well-preserved. Parts of city fortifications, spaces without a real use, were changed into parks and promenades. ${ }^{44}$ This shift of function considerably altered their meaning and the city's identity without completely changing their

\footnotetext{
${ }^{38}$ KRAJNIK - PETROVIĆ KRAJNIK 2019 (see in note 34), p. 414.

${ }^{39}$ Ibidem, p. 410.

${ }^{40}$ Ibidem, p. 410.
}

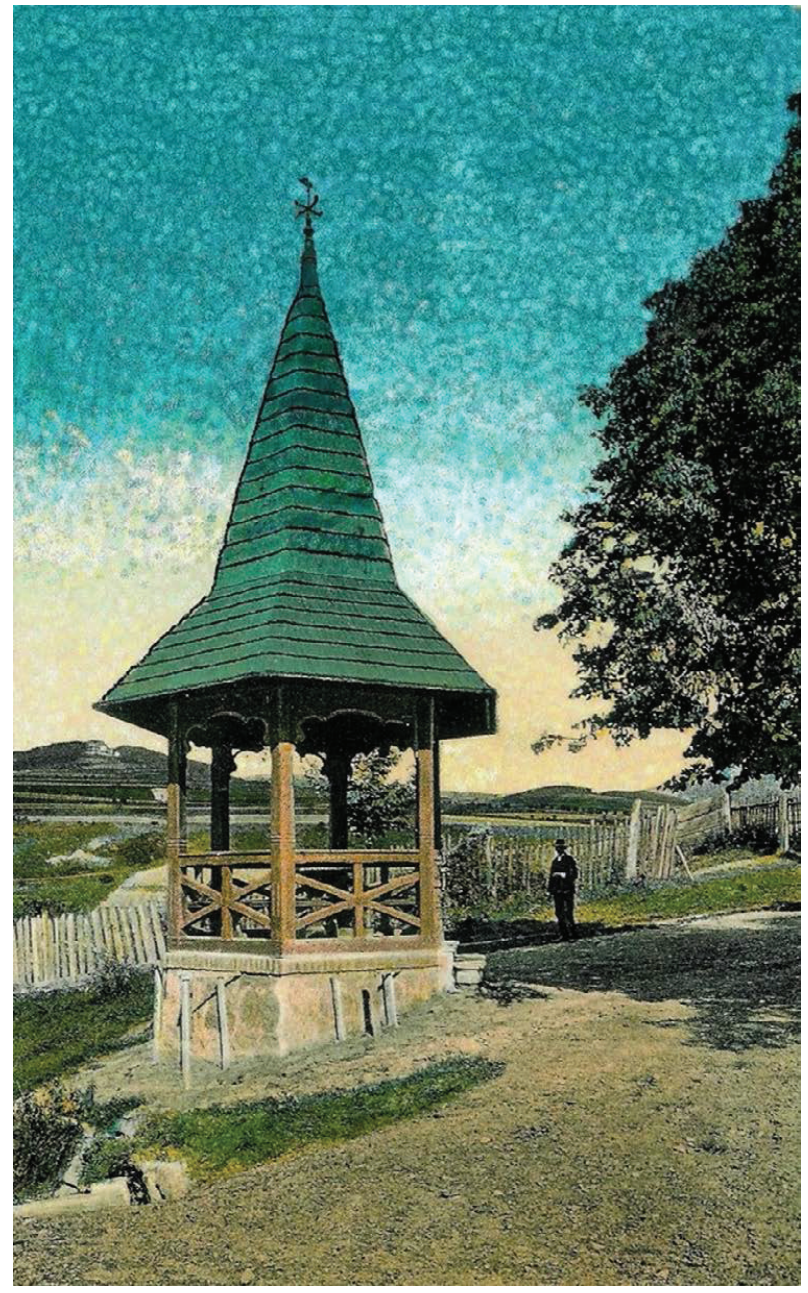

Fig. 4: Summer house in the public park. Schiessplatz at the end of the 19th century, Levoča. Photo: Levoča Information Office.

appearance. The function of walled structures got transformed from defensive to a more recreational and has also introduced new ways of consuming and experiencing such architectural structures by the public. This shift of the walls' use modified the identity of the town and the meaning of the walls -

${ }^{41}$ Ibidem, p. 415.

${ }^{42}$ CHALUPECKÝ 1975 (see in note 15), p. 146.

${ }^{43}$ Ibidem, p. 149.

${ }^{44}$ KRAJNIK - PETROVIĆ KRAJNIK 2019 (see in note 34), p. 409. 
structures used for killing and defence became used by the public as leisure zones and the walled city was no longer seen as a place of refuge, thus changing its urban identity. Moving on to the present, after losing their defensive function, city walls across $\mathrm{Eu}-$ rope now act as historical and civic monuments. By the beginning of the $20^{\text {th }}$ century, the fortifications of Levoča finally became recognised as historical and cultural heritage. ${ }^{45}$ From a contemporary point of view, Levoča can be categorised into "the more widespread phenomenon" of a town surrounded by medieval defensive walls that essentially became civic monuments, as presented by Creighton and Bruce. ${ }^{46}$ The military and defensive function of the fortifications became symbolic, reflected in their importance as cultural and historical monuments. These architectural structures, once important for defending the city, now create only a fragment of it. According to some, since they lost their defensive function, they also lost their original architectural purpose. Thus we tend to consider them from a purely urban viewpoint rather than from an architectural one, as it seems that they have no real purpose but to form a part of the town. ${ }^{47}$ On the other hand Hirst states that one should not think of the fortress in "purely utilitarian terms". ${ }^{48}$ According to him, fortresses cannot be defined as "engineering pure and simple". ${ }^{49}$ They can be undoubtedly seen as something symbolic, not just as something functional, which is primarily the case of the present, since they no longer fulfil their pragmatic defensive purpose. ${ }^{50}$ Despite the fact that the defensive function of the walls disappeared due to geopolitical changes in society that had occurred during the $18^{\text {th }}$ century, their symbolic function still remains present today. City walls thus became monuments that bear the unique identity of the city and commemorate the past.

\footnotetext{
${ }^{45}$ LUKÁČ, G.: Aktualizačný list národnej kultúrnejpamiatky (Krajský pamiatkový úrad Prešov - pracovisko Levoča). Levoča 2003.

${ }^{46}$ BRUCE - CREIGHTON 2006 (see in note 3), p. 3.

${ }^{47}$ ROSSI, A.: The Architecture of the City. Cambridge 1999, p. 115.

${ }^{48}$ HIRST 1997 (see in note 38), p. 20.

${ }^{49}$ Ibidem, p. 20.
}

Moreover, just as in the past walls divided societies by creating social differences, today they divide the past from the present. This can be understood symbolically but also literally as in Levoča, the walls act as a border between the historic centre and the newly built parts of the town. Therefore, city walls contributed to the creation of a new urban identity, allowing the city to grow outside of them but at the same time conserving the historic centre inside of them. They not only facilitated conservation of historic buildings of the city centre, but also helped to preserve the authentic identity of the town. Therefore, in this case city walls, in addition to fulfilling their symbolic purpose, they acquired a new urban function - physically preserving the identity of the city and its authentic historical monuments.

Overall, despite the fact that city fortifications lost their original defensive function, they have acquired a new symbolic one. Creighton argues that it is important not to "create a false dichotomy between the 'military' and 'symbolic' importance of town walls". 51 We have to recognise both, physical and social aspects of such built-environments, since they act as important sources of identity conveying a meaning. ${ }^{52}$ It would be wrong to claim that city walls have no function in the present day. Despite not defending the town physically, they serve as historical monuments and symbols of the city itself. It is the shift of function as well as the change of perception of the fortifications by the public, the inhabitants of the city as well as the tourists, what creates an individuality and a unique character of the city. ${ }^{53}$

\section{City Walls - Symbol or Brand?}

Creighton argues that identity of a town can very much depend on the fact whether it was surrounded

\footnotetext{
${ }^{50}$ Ibidem, p. 20.

${ }^{51}$ CREIGHTON - HIGHAM 2005 (see in note 25), p. 207.

${ }^{52}$ EL NACHAR, E. - ABDEL-HADI, A.: Place Identity / Place Making in the Built Environment - Towards a Methodological Perspective. In: Cities' Identity through Architecture and Arts. (Ed. al.). London 2018, p. 78.

${ }^{53}$ CREIGHTON 2007 (see in note 2), p. 344.
} 
by city walls, its historical position in the past and its political and economic importance. ${ }^{54}$ It has been claimed that small European walled towns, usually have a lot in common in terms of civic identity or community spirit in general. ${ }^{55}$ Slovak towns Levoča and Bardejov, two visually very similar medieval royal towns, surrounded by city walls illustrate this point. However, each of them has got its own distinctive urban identity which is linked to specific historical and cultural monuments and so it would be wrong to generalise about their circumstances. ${ }^{56}$ It has been proved that "community identity or identities are often closely related to the extant physical remains". ${ }^{57}$ Therefore certain architectural elements, such as city fortifications, contribute to the creation of a unique identity of a town, which can be seen as the foundation of community pride. ${ }^{58}$ In the past, city walls were seen as a key characteristic of civic status and independence. ${ }^{59}$ James Tracy further argues that "people became attached, not so much to the mere possession of a wall, but rather to a particular architectural image". ${ }^{60}$ Thus the visual image of city walls can be seen as an essential element for the perception of the city by its inhabitants and for the creation of the city's unique character. This section will explain how the city of Levoča and its identity were presented in the past in visual sources and how the town is presented today. It will discuss whether city walls act as a symbol of a city or a brand.

Representation of a town in visual sources is a significant factor in the construction of its identity. As Brezovec and Bruce pointed out, town walls help to create a characteristic image of the city and they act as an element of pride which was often depicted by its inhabitants in a town's insignia, such as town

\footnotetext{
${ }^{54}$ BRUCE - CREIGHTON 2006 (see in note 3), p. 1.

${ }^{55}$ Ibidem, p. 1.

${ }^{56}$ CREIGHTON - HIGHAM 2005 (see in note 25), p. 166.

${ }^{57}$ BRUCE - CREIGHTON 2006 (see in note 3), p. 2.

${ }^{58}$ ELEWA 2018 (see in note 5), p. 473.

59 TRACY 2009 (see in note 24), p. 583.

${ }^{60}$ Ibidem, p. 583.
}

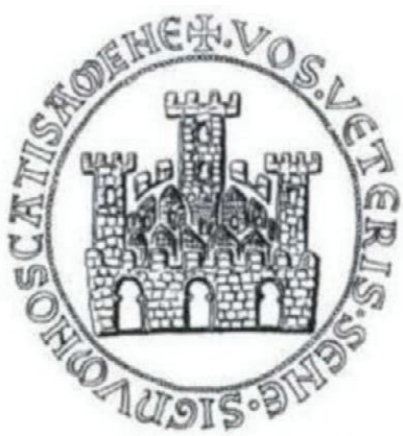

Fig. 5: First city seal of Siena from the 13th century. Line drawing of matrix, o 61,5 mm. Photo: Museo Nazionale del Bargello, Florence, Italy.

crest or a seal. ${ }^{61}$ In other words, "it was necessary to provide the towns and cities with a specific and respective symbolic image". ${ }^{62}$ This can be illustrated by a number of examples of European fortified towns, such as Siena and Arles, whose civic seals depict fortresses referring to the cities' fortifications (Fig. 5). ${ }^{63}$ In the case of Levoča, it is the seal of the Community of Spiš Saxons (Fig. 2), in which the town gained the leading position in 1271, considered one of the most important early depictions of the city. Additionally, in this year Levoča was historically mentioned as a 'town' for the first time as civitas provincie capitalis - capital of the Community of Spiš Saxons. ${ }^{64}$ This seal dates back to the last quarter of the 13th century and depicts a simple fortress a defensive tower with a Gothic roof standing on a mead between two trees. Despite its simplicity, it is one of the most important early depictions of the town, prior to the veduta work of later periods. There is a description, SIGILLV M SAXONVM DE

${ }^{61}$ BREZOVEC, T. - BRUCE, D.: Tourism Development: Issues for Historic Walled Towns. In: Management, Issue 2, 2009, no. 4, p. 106

${ }^{62}$ SABATE 2015 (see in note 4), p. 7.

${ }^{63}$ KLINKENBERG, E. S.: Representations of Architecture on Early City Seals in the Holy Roman Empire: References to Aurea Roma on Royal and Imperial Bulls. In: Pourquoi les sceaux? La sigillographie, nowvel enjeu de l'histoire de l'art. Lille 2011, pp. 365-382.

${ }^{64}$ CHALUPECKÝ 1975 (see in note 15), p. 54. 
CIPS and the tower is leaning against a Hungarian double cross. ${ }^{65}$ According to Novák, town walls in iconography were seen as the most distinctive feature of walled cities, something that could not be overlooked. ${ }^{66}$ The importance of city fortifications as symbols of walled towns is only highlighted in the fact that they were a distinguishing element between towns in the Kingdom of Hungary that possessed the royal status and those that did not, since construction of city fortifications was a royal privilege. This is further supported by Novák, who states that "symbols of the oldest towns that became self-governing institutions by the beginning of the second half of the 13th century consisted of a topographic motive - town fortifications". ${ }^{67}$

Moreover, Vrtel claims that in heraldry, tower symbolises refuge, fortress, impregnability or vigilance. ${ }^{68}$ This symbolism is further developed by Tracy, according to whom, "If walls and gates were associated with the identity and sovereignty of the city, the fortress was associated with the authority of an imperial power". ${ }^{69}$ This emphasises the importance of city walls as symbols of a city's distinctive character. However, although it is possible to identify this symbolism in the seal of the Community of Spiš Saxons, it is important to note that this symbol possibly refers to the fortification of the city in form of its first walls and not to the fortification system as we know it today. Therefore, it was not an accurate depiction of the fortifications, but rather an expression of symbolism and identity of the royal fortified town. ${ }^{70}$ City fortifications were in this case the most distinctive feature of these towns, acting as symbols of their unique identity.

Vedute, or detailed landscape paintings of cities were another very significant way of visual rep-

\footnotetext{
$\overline{{ }^{65} \text { SUCHÝ } 1974 \text { (see in note 7) }}$, p. 99.

${ }^{66}$ NOVÁK, J.: Pečate miest a obci na Slovensku. Bratislava 2008, p. 13.

${ }^{67}$ Ibidem, p. 13.

${ }^{68}$ VRTEL, L.: Heraldické symboly. Bratislava 2014, p. 165.

${ }^{69}$ TRACY 2009 (see in note 24), p. 589.

${ }^{70}$ NOVÁK 2008, (see in note 66), p. 13.
}

resentation of cities, labelled by Robert Simůnek as "ancient photographs". ${ }^{71}$ According to Kostof, consideration of two-dimensional maps and vedute focuses attention on cities as a whole, rather than on their individual components. ${ }^{72}$ Thus the aim of vedute was to depict the town as a unit, rather than just its dominant features. This is a big contrast to the depiction of cities in seals, mentioned previously, where the cities were often represented only by their dominant features, such as city walls. Nevertheless, with visual representations such as vedute, it is important to note the fact that they were often "filtered through the eye and mind of the imagemaker, patron, and viewer, they reveal contemporary interpretations as well as ideological biases". ${ }^{73}$ Thus it is important to consider the subjectivity of these visual sources, as they were not meant to reflect the landscape as it looked like, but rather as it should have been seen. ${ }^{74}$

A good example is the $18^{\text {th }}$ century veduta painted by the Levoča goldsmith, Ján Szilassy, installed on an enamel medallion decorating a golden chalice (Fig. 6). It depicts a specific event - the 1749 fire of the town. In this instance, the aim of the author was not to depict the identity of the fortified royal city, but to portray its dominant features that were affected by the fire. On the contrary, the veduta from 1618 showing the panorama of the town from north-east (Fig. 7) depicts the whole city, where the fortification system is clearly visible. Therefore, it is the objective behind each visual representation of the town which is key here. If the intention of the author was to depict the status and the identity of the town, specific symbols or dominant features of the city, such as walls were clearly visible. Conversely, if the intention of the author was to document a cer-

\footnotetext{
${ }^{71}$ ŠIMƯNEK, R.: Kulturní Krajina na Starých Vyobrazeních. In: Studia Historica Nitriensia, 19, 2015, no. 1, p. 5.

${ }^{72}$ FAVRO, D.: Meaning and Experience: Urban History from Antiquity to the Early Modern Period. In: Journal of the Society of Architectural Historians, 58, 1999, no. 3, p. 366.

${ }^{73}$ Ibidem, p. 366.

${ }^{74}$ ŠIMƯNEK 2015 (see in note 71), p. 5.
} 


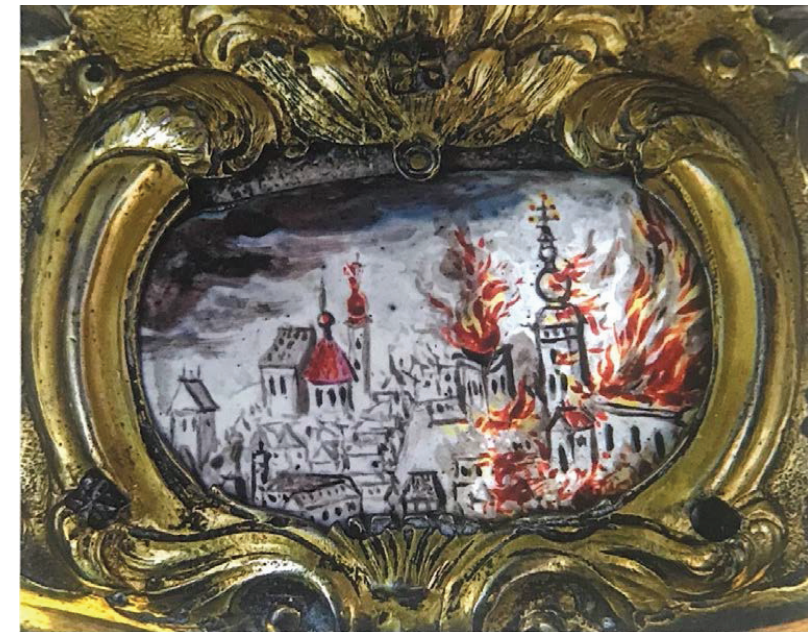

Fig. 6: Ján Szilassy, Levoča on fire, 1749. Painting. Repro: Bobáke, I.: Bazilike sv. Jakuba v Levoči. Bambow 2016.

tain event, such as the mentioned fire, emphasis was placed on objects affected by the fire. Hence visual sources can represent the city as it should have been seen, depending on the aim of the author. This is further supported by Benevolo, who claims that painters were both "active participants" in the setting of the collective identity of the citizens and "agents of its representation". ${ }^{75}$ Depiction of city walls in sources like vedute played an important role in constructing identity of walled towns. Consequently, city walls in this instance act as a symbol of the town.

Moving on to the present, from a contemporary point of view, symbols of towns such as city walls, often become associated with branding of such cities mainly in the context of tourism. This has to do a lot with their representation and their perception by the tourists. The city of Levoča is no longer presented as a free royal town as it used to be in the past, but rather as a European "gem city". This term, developed by Ashworth and Tunbridge presented on the example of the German town Rothenburg ob der Tauber, refers to a "time-frozen and later treasured cityscape". ${ }^{76}$ European walled towns such as Levoča

\footnotetext{
${ }^{75}$ BENEVOLO, L.: The European City. Oxford 1995, p. 41.

${ }^{76}$ BRUCE - CREIGHTON 2006 (see in note 3), p. 2.

${ }^{77}$ Ibidem, p. 2.
}

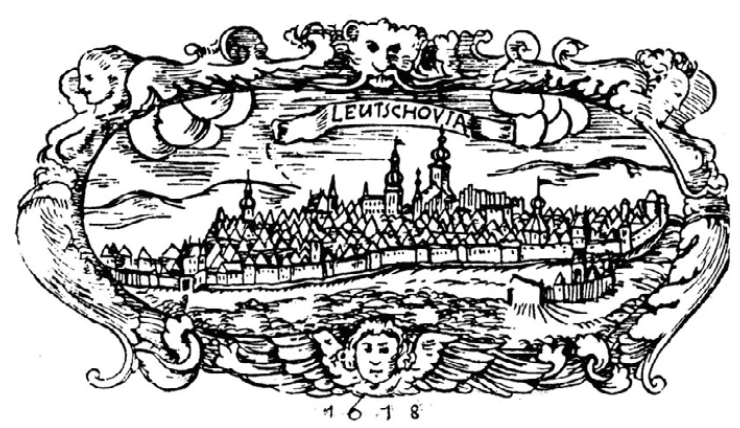

Fig. 7: Levoča depicted on a veduta from 1618. Photo: Slovak National Archive.

or Toledo illustrate this point very accurately, as in these cities, the historic town surrounded by the city walls has been well-preserved to the present day. In the case of the "gem city" of Levoča, it was thanks to the lack of urban and social development during the last two centuries that the historic centre, encircled by the city walls, has become fossilised, conserved or even treasured. Although this can be seen as an advantage for preservation of historic sites, such cities "cannot compete with urban development of their counterparts," as there is no room for any modern construction. ${ }^{77}$ This is supported by Brezovec and Bruce, who claim that "while the walls are often seen as a positive element for tourism and act as an attraction for tourists, they also represent a barrier for further development". ${ }^{78}$ Therefore, defensive structures such as city walls can paradoxically become a sign of vulnerability of the town. Demolition of fortifications was in some cases "beneficial in terms of urbanism and city growth", such as in the cases of Bruges, Budapest or Cologne, as these cities could grow, develop and thus become more attractive for tourists. $^{79}$

\footnotetext{
${ }^{78}$ BREZOVEC - BRUCE 2009 (see in note 61), p. 102.

${ }^{79}$ BRUCE - CREIGHTON 2006 (see in note 3), pp. 2-5.
} 
On the other hand, in cities such as Levoča, construction inside the city walls became almost impossible, as the walls act as borders that cannot be surpassed. Having said that, the city became "frozen in time" only partially. Fortifications surround the well-preserved historic centre, but they were not seen as an obstacle for further urban growth outside of them. In other words, the city itself grew and many different districts have been built outside the walls, while still preserving the historic buildings within them. Furthermore, within this context of urbanisation and globalisation, there has been a concern about towns losing their identity due to these changes. ${ }^{80}$ Therefore, the model of "gem cities", in this case, can be seen as a positive concept. This is mainly due to the fact that city walls contribute to the preservation of such historic cities and their unique identity. They embody a boundary between the past and the present, surrounding the well-preserved historic centre and not allowing any modern interventions within the walled structures. Since the city walls of Levoča clearly divide the modern and the historical parts of the town, they can therefore "provide the experience of authentic medieval urban space with a clear delimitation of the inner and outside world". ${ }^{81}$ Thus, city walls not only offer two separate experiences for the viewers, but also preserve the town's unique character and act as a symbol of the town.

Moreover, within the modern context of tourism, a unique urban identity can be seen as a way of promoting the city, acting as "an economic tool that can boost city branding among the other competitive global cities". ${ }^{82}$ Hence, city walls can become a source of revenue for the town. ${ }^{83}$ It is especially the tourists who can see them as a brand of the town, representing a landmark or an attraction that determines the identity of the city. This is shown in the example of Levoča, which is known mainly

\footnotetext{
${ }^{80}$ ELEWA 2018 (see in note 5), p. 471.

${ }^{81}$ BREZOVEC - BRUCE 2009 (see in note 61), p. 106.

${ }^{82}$ ELEWA 2018 (see in note 5), p. 473.

${ }^{83}$ CREIGHTON - HIGHAM 2005 (see in note 25), p. 244.

${ }^{84}$ BRUCE - CREIGHTON 2006 (see in note 3), p. 14.
}

thanks to its city walls. Fortifications can therefore become a feature that distinguishes the town from others in the eyes of tourists. Hence the concept of "gem cities" can serve as a branding for the city. However, there are dangers that the city becomes a sterile "museum town" - attractive only for touristic interests, especially with examples of "gem cities" like Levoča. ${ }^{84}$ In other words, cultural and historical heritage such as city walls, used as a brand of the city in marketing to make the town a more popular touristic attraction, undermines in some ways the original identity of place.

Overall, identity of walled towns has changed over the centuries, as well as the way these towns are presented, as shown in the example of Levoča. The town has changed from being a free royal walled town in the past, to a "gem city" in the present. In such examples, city walls can act as tourist attractions on their own. ${ }^{85}$ However, to label these towns as mere tourist attractions would be wrong, as "historic walled towns are powerful vehicles of meaning" ${ }^{86}$ Walled cities thus not only commemorate the unique identity of such towns of the past, seen in the case of Levoča, but they also convey a more contemporary meaning of valuable cultural heritage. ${ }^{87}$ The coexistence of both aspects, symbol and brand of the city, maintains a distinctive local character of the city. In order to maintain the power of the brand, it is important to recognise the city walls as a symbol of the city.

\section{Preserving Urban Identity}

According to the Charter for Conservation of Historic Towns and Urban Areas, conservation of historic towns and other historic urban areas should form a significant part of urban and regional development. ${ }^{88}$ Europe's walled towns take a special place within the context of conservation of historic towns, since international organisations such as

\footnotetext{
${ }^{85}$ BREZOVEC - BRUCE 2009 (see in note 61), p. 102.

${ }^{86}$ UNESCO: Walled Cities and Open Societies \& Open Societies: Managing Historic Walls in Urban World Heritage Properties, 2017.

${ }^{87}$ Ibidem.

${ }^{88}$ CREIGHTON 2007 (see in note 2), p. 351.
} 
UNESCO or the Walled Towns Friendship Circle have recognised them as a valuable cultural and historical heritage. Although it is certain that city walls act as an important cultural heritage which should be preserved for future generations, it is often questionable why and how this should be done. According to the Washington Charter, qualities to be preserved should include "the historic character of the town or urban area and all those material and spiritual elements that express this character" ${ }^{89}$ Therefore, individual historical monuments that form part of cities, such as city fortifications, should be conserved in order to preserve and protect the city's identity. Regarding their conservation, questions about authenticity, heritage management and touristic profit are often raised. This section will seek to explain why touristic profit should not be the leading force behind monuments preservation. Furthermore, it will discuss the impact of reconstruction of the Košice Gate in Levoča on the authenticity and identity of the town. By arguing that preservation of city walls contributes to protection of the unique urban identity, this section will explore ideas behind conservation of town fortifications, their future use and presentation.

The reasons for preserving city walls has been a much-debated issue among conservationists. For some, it is the aesthetic and historical aspects that are mostly valued, while others argue that city walls should be preserved because they are a form of good heritage marketing. ${ }^{90}$ Consequently, touristic profit and branding of walled towns are often the leading forces behind their conservation. In many cases, after town walls had lost their defensive function, their landscapes were either reconstructed, conserved or repaired to be beneficial for the public and visitors. ${ }^{91}$

\footnotetext{
${ }^{89}$ INTERNATIONALCOUNCIL ON MONUMENTS AND SITES: Charter for the Conservation of Historic Towns and Urban Areas. Washington DC 1987.

${ }^{90}$ SLATER, T.R.: Conserving Europe's Historic Towns: Character, Managerialism and Representation. In: Built Environment (1978-), 23, 1997, no. 2, p. 147.

${ }^{91}$ MOSLER, S.: Everyday Heritage Concept as an Approach to Place-Making Process in the Urban Landscape. In: Journal of Urban Design, 2019, no. 24:5, p. 783.

${ }^{92}$ Ibidem, p. 784.
}

They "played an important role in attracting tourists to these cities, becoming a heritage tourism magnet" after becoming recognised as cultural and historical monuments in the $20^{\text {th }}$ century. ${ }^{92}$ This happened after decades of being ignored by the heritage industry and the public, being seen as "mostly not identifiable and picturesque, as they were generally just forms in the earth or ruins that were seen as creating non-aesthetic conditions". ${ }^{3}$

Some even claim that walled towns have some kind of an advantage over other historic towns, since city fortifications are attractive for tourists and due to their atmosphere, can create a unique historical experience for the public. ${ }^{94}$ This can be illustrated by European walled cities such as Levoča or Toledo, which thanks to their city walls, managed to preserve their unique historical atmosphere and character. Touristic profit can thus be seen as a positive thing, as income generated through heritage tourism can be vital to cities, "creating commercial value and supporting heritage conservation". ${ }^{55}$ Therefore, profit created through tourism could possibly help with future conservation of city's historical monuments. On the other hand, preservation of monuments only for tourism can lead to "museumification" of these cities, as has been argued previously. ${ }^{96}$ Consequently, heritage management runs the risk of towns losing their character over tourism, becoming "stage sets... for economic exchange". ${ }^{97}$ Such a phenomenon can be observed in the originally medieval city of Carcassonne. This city, restored in the $19^{\text {th }}$ century, is simultaneously considered a successful provider of attractive heritage, and "little more than a stage-set for mock medieval displays and tawdry souvenir shops that demonstrate the primacy of economic exchange". ${ }^{98}$ In other words, tourism focused con-

${ }^{93}$ Ibidem, p. 783.

${ }^{94}$ BREZOVEC - BRUCE 2009 (see in note 61), p. 102.

${ }^{95}$ MOSLER 2019 (see in note 91), p. 779.

${ }^{96}$ BRUCE - CREIGHTON 2006 (see in note 3), p. 14.

${ }^{97}$ Ibidem, p. 7.

${ }^{98}$ GRAHAM, B.: Heritage as Knowledge: Capital or Culture? In: Urban Studies, 39, 2002, nos. 5-6, p. 1017. 
servation can lead to walled towns losing their unique identity and becoming little more than "museum towns" for tourists.

Nevertheless, as it has been argued before, "places of bastion fortifications in many European cities represent valuable cultural heritage and a recognizable element of urban identity". ${ }^{99}$ The intangible values fortifications represent should be equally preserved as their physical aspects. By conserving their physical features, which usually act as magnets for tourists, we are also preserving the unique identity of walled towns. It is the identity of the city represented by these structures, which is made of "the physical components and cultural spirit". ${ }^{100}$ Therefore, both tangible and intangible aspects of conserved walled towns are important in the process of preserving their identity. However, it is not only the preservation process, but also the presentation of conserved and restored objects, which can have an impact on the identity of the town and on its perception by the public, since the walled city used to be and often still remains identified by its town walls. ${ }^{101}$

When talking about the preservation process, the question of authenticity often comes to mind, as it can be a valuable element adding a historic charm to the city's character. The Spanish city of Ávila is an exceptional example of a medieval fortified city whose "surrounding walls are fully intact". ${ }^{102}$ On the other hand, in our example of Levoča, appearance of the city fortifications is not authentically medieval. The fortification wall is preserved in the extent of $80 \%$ of its original length, including two of the three original gates and about $40 \%$ survives in its complete original form. ${ }^{103}$ Some objects of the city walls such as bastions or gates have been demolished over the past two centuries, such as the Lower Gate, but the fortification system still consists of many authentic features. ${ }^{104}$ The walls have under-

\footnotetext{
99 KRAJNIK - PETROVIĆ KRAJNIK 2019 (see in note 34), p. 413.

${ }^{100}$ ELEWA 2018 (see in note 5), p. 473.

${ }^{101}$ UNESCO, Walled Cities and Open Societies \& Open Societies: Managing Historic Walls in Urban World Heritage Properties.

${ }^{102} \mathrm{ZHOU}, \mathrm{J}:$ The Legacy of Walled Cities. In: World Heritage Review, 91, 2019, p. 8.
}

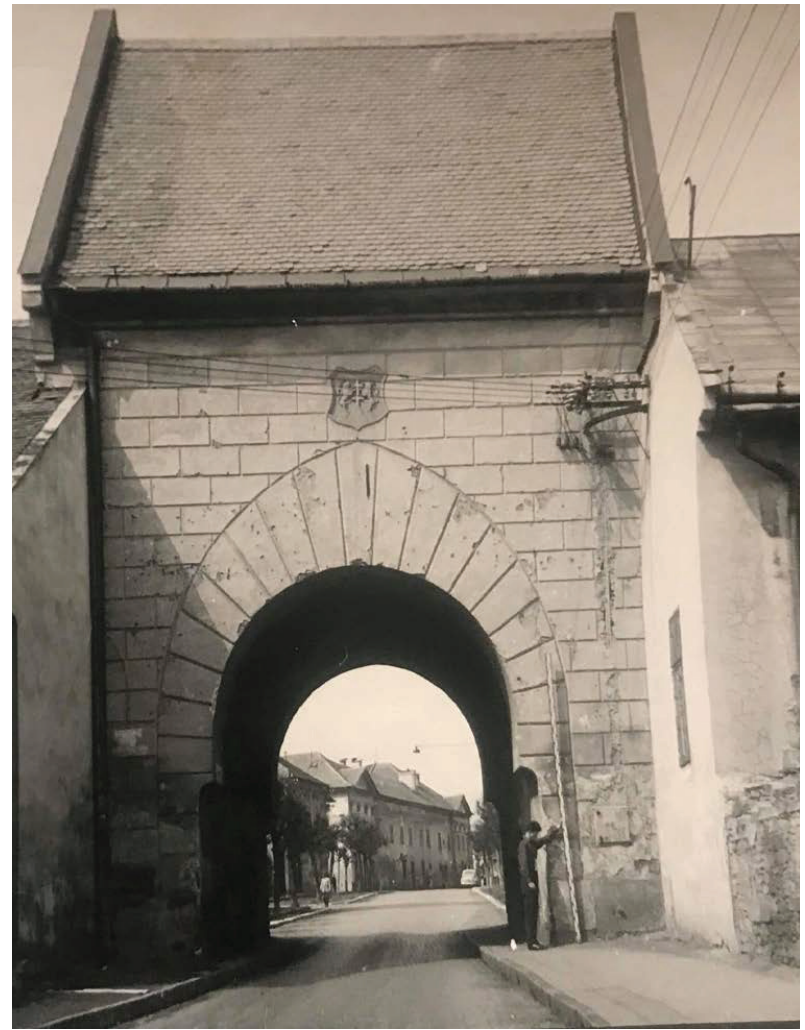

Fig. 8: Kosice Gate in Levoća before the 1980s reconstruction. Photo: Archive of the Monuments Board of the Slovak Republic.

gone some renovations and alterations during the centuries. Several of them were minor, but others were more extensive and some even "enhanced" the views of the town. ${ }^{105}$ This can be illustrated by the example of the Košice Gate, built approximately in the first half of the 14th century and later rebuilt a number of times, for instance in 1840 (Fig. 8) ${ }^{106}$. During the most-recent renovation which happened during the 1980s, the gate was given its present-day appearance (Fig. 9). ${ }^{107}$ The proportions of this gate

\footnotetext{
${ }^{103}$ UNESCO: Advisory Body Evaluation (Levoča, Spišský Hrad and the Associated Cultural Monuments). ICOMOS 2009.

${ }^{104}$ LUKÁČ 2003 (see in note 45).

${ }^{105}$ BRUCE - CREIGHTON 2006 (see in note 3), p. 14.

${ }^{106}$ CHALUPECKÝ 1975 (see in note 15), p. 142.

${ }^{107}$ LUKÁČ 2003 (see in note 45).
} 


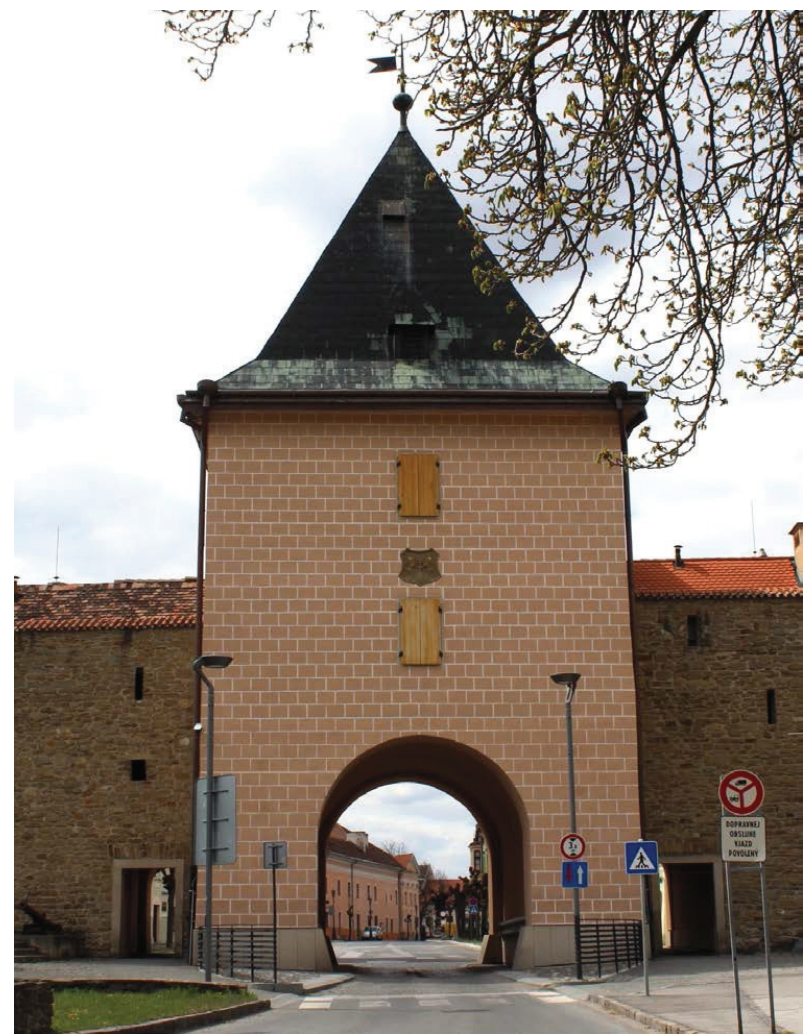

Fig. 9: Kosice Gate after the 1980s reconstruction - present-day situation. Photo: Author's archive.

were considerably altered - the gate got wider, two floors were added and also the roof was changed from gable to pyramid. The façade is no longer rustic, but rather smooth imitating an ashlar wall type of façade.

It is an example of reconstruction that has "elevated to the public eye an historic symbol of civic pride and identity", as city gates were considered "faces of the city". ${ }^{108}$ Although the importance of city gates vanished with the transition to modernity, as Walter Benjamin once said, "what we can learn from their history is the art of granting a city its character". ${ }^{109}$ Thus it is important for a city gate to be restored and presented as an emblematic piece of architecture not only for the tourists, but also for the town's citizens,

\footnotetext{
${ }^{108}$ CREIGHTON - HIGHAM 2005 (see in note 25), p. 244.; JÜTTE 2014 (see in note 1), p. 210.

109 Ibidem, p. 227.
}

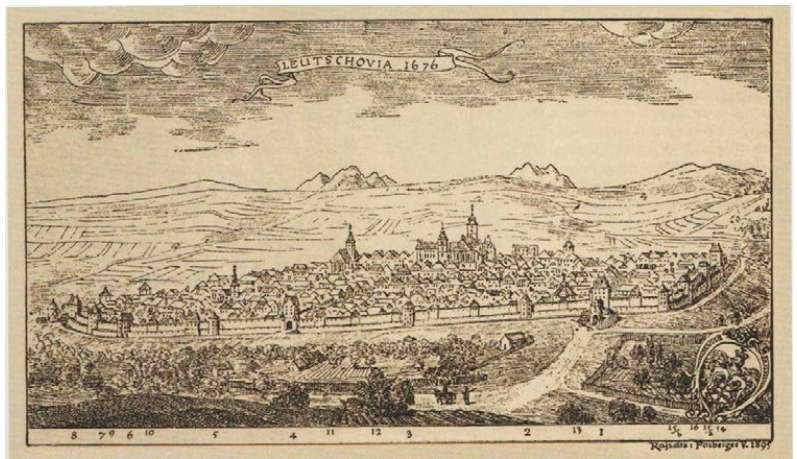

Fig. 10: 1676 Veduta showing Levoča. Repro: Collective of Authors: Levoča: Národná kultúrna pamiatka. Bratislava 2017.

reflecting the city's identity. The reason behind this renovation was possibly an attempt to make the gate look more authentic, probably getting inspiration in the 1676 veduta (Fig. 10). When compared, there are some similarities between the present-day gate and its appearance in 1676, such as three floors and its width. However, the windows look completely different and also the barbican before the gate is missing. It is questionable whether this reconstruction made the fortification system look more historically accurate, or if it made the gate look more artificial, similarly as we saw with the reconstruction of Carcassone's fortifications. Considering the fortification system as a whole, the Košice Gate reconstruction can be seen as a positive change. As Daniel Jütte argues, "The combination of military needs with the requirements of symbolic representation ensured that gates were often far more lavish from an architectural point of view than the rest of the city wall". ${ }^{110}$ Therefore, compared with the 1840 appearance, the 1980 reconstruction has undoubtedly made the gate look more representational, acting as "a pars pro toto for the entire city". ${ }^{111}$ By making the gate taller and more robust, the reconstruction has highlighted the symbolic meaning of the gate.

Despite the fact that the Košice Gate is no longer the real entrance to the city, in the present it

\footnotetext{
${ }^{110}$ Ibidem, p. 209.

${ }^{111}$ Ibidem, p. 210.
} 
represents an entrance to the historic centre of the town which is surrounded by the city walls and thus allows the viewer to experience the unique identity of the city and its historical character. Therefore, although this considerably extensive renovation of city walls altered the image of the city to a great extent, it has not changed its identity and character, since the objective of this renovation was to imitate the gate's historical appearance. On the other hand, some may argue that the 1840 appearance of the gate was more authentic, especially considering the details, such as the rustic façade and the pseudo gothic arch. There is therefore an open scope for debate about this reconstruction. Nevertheless, undoubtedly for the inhabitants of the town this reconstruction made the gate look more representational and highlighted the historic importance of the city's historic identity of a royal town. It is also an example of reconstruction of a historical monument which made the fortification system and the city itself more attractive for the tourists.

After city fortifications are conserved, they often acquire new functions, besides those symbolic, which "play an important role in the historic urban landscape and cultural identity of walled cities". ${ }^{112}$ According to Creighton and Bruce, "effective management is best achieved, where the circuit is not divorced from its urban context but treated holistically in the context of the townscape and its setting". ${ }^{113}$ Thus, management of conserved city walls is best done when the preserved buildings still form a part of the city's infrastructure and are not divorced from the urban fabric. Assigning them the correct use can also be beneficial in this process. In Slovakia for example, besides tourism, allocating them new public functions, such as museums or city archives became another reason behind their restoration. ${ }^{114}$ This can be observed in the example of Levoča, where a number of bastions today serve as restaurants and hotels. Another example would be

\footnotetext{
112 ZHOU 2019 (see in note 102), p. 11.

${ }^{113}$ BRUCE - CREIGHTON 2006 (see in note 3), p. 11.

${ }^{114}$ GREGOROVÁ, J.: Obnova torz architektúry ako špecializovaná architektonická disciplína. In: Archaeologia Historica, 40, 2015, p. 32.
}

the Estonian capital Tallinn, where parts of city walls, such as bastions are now used as museums. ${ }^{115}$ It is a good way of re-integrating buildings that did not have a proper use in the past, into the present-day life of the city. Thus, conservation of walled structures for the sake of public use contributes to preservation of the city's identity. In other words, the conservation process makes the fortification complex look more authentic and assigning new functions to parts of fortifications contributes to a better reintegration of these structures into the community life.

Consequently, conservation of city walls also introduces new ways of consuming these structures, as they often acquire new public functions. It also makes the inhabitants of the city aware of the importance of conservation of city walls and makes them active participants in this process. ${ }^{116}$ This is especially the case of parts of fortifications, such as bastions, which became restaurants or museums, as has been argued above. However, there are some instances, where places of bastion fortifications and their surroundings are not well used by the public and often either deteriorate or are given rather inappropriate functions. Such a phenomenon can be observed in the fortification complex of Levoča, especially on the eastern part of the walls, where the former moat is currently used as a car park, which degrades the visual image of the walled city. There is no doubt that this space could have a much better use, especially considering the historical and present-day importance of the city walls for the identity of the city and its image. Examples of Slovak walled towns such as Trnava or Bardejov show a completely different approach towards using such spaces by the public. For instance, the former moat of the Bardejov city fortifications is indicated by a water fountain and serves as a public park (Fig. 11). ${ }^{117}$ Using a water element, such as a fountain, in the space of a former moat, not only makes the space more visually attractive for the public, but it also introduces a more sustainable

\footnotetext{
${ }^{115}$ UNESCO, Walled Cities and Open Societies \& Open Societies: Managing Historic Walls in Urban World Heritage Properties.

${ }^{116}$ ELEWA 2018 (see in note 5), p. 473.

117 GREGOROVÁ 2015 (see in note 114), p. 35.
} 
approach towards conservation and future use of city fortifications. Such concept is very up to date, as many towns are trying to bring more ecological elements to their urban fabric.

A similar example is Trnava, where the same part of city walls, the former moat, is nowadays used as a public green park. ${ }^{118}$ Thus, such a sustainable approach towards preservation and future use of places of bastion fortifications can have a positive impact not only on the visual image of the town, by adding to it some aesthetic value, but it can also introduce a form of sustainable tourism. This can be done by bringing more elements of green urbanism into the walled cities, such as green parks, fountains or lakes. This concept can lead to a "more sensitive and responsible approach and lead to sustainable development of walled cities in the long term". ${ }^{119}$

Each of these matters is crucial to effective conservation of town walls, which can create a unique living environment for residents, but also can attract more tourists, acting as "sustainable gems of urban conservation". ${ }^{120}$ However, it is important that the preservation and presentation of conserved fortifications also introduce new functions which are in "accordance with the original character of the fortification and must not disrupt urban, architectural and landscape values of the area". ${ }^{121}$ In other words, in order to preserve the urban identity of the city, the new functions and uses of the conserved fortifications should not disturb the urban layout and the visual image of the city. Nevertheless, introduction of more sustainable elements of green urbanism into spaces of preserved fortifications can have a positive impact on the city's appearance and preservation of its identity, as seen in the examples of Bardejov and Trnava.

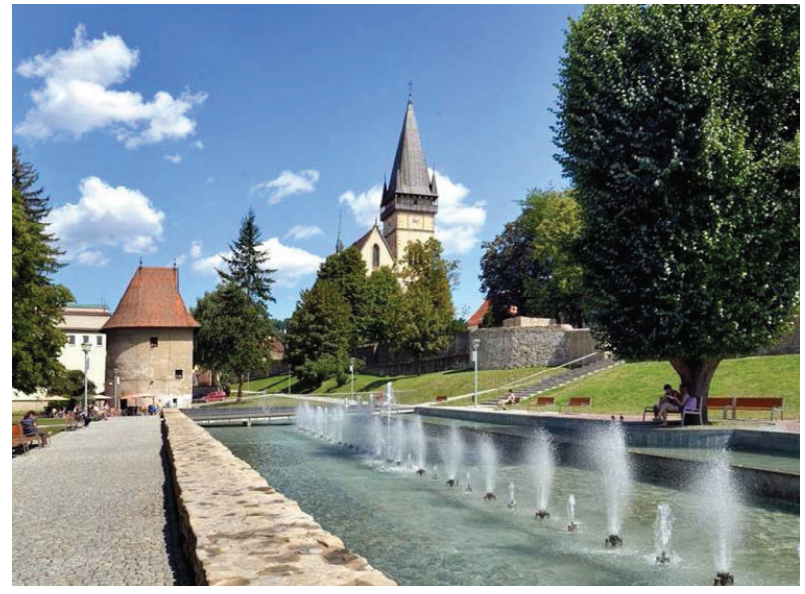

Fig. 11: Fountain in Bardejov, Slovakia. Photo: http:/ / wmw.vypadni.sk/ sk/spievajuca-fontana-v-bardejove. (Fountain and a green park replaced the former moat of the Bardejov city fortifications.)

In summary, adequate preservation of city walls and the process of allocating them new functions, can contribute to preservation of the distinctive identity of walled towns. As Brezovec and Bruce argue, "since the walls are unique to each town, they are also an important landmark and often act as an element of identity for the town's residents". ${ }^{122}$ If they are effectively managed, they can create a unique and valued living space for residents, but also for tourists. It is also the visual image of the conserved city, that can have a great impact of the city's perception by the public, as has been shown on the example of the Košice Gate in Levoča. Additionally, a more sustainable approach towards future use of the city walls and their presentation can have a positive impact on preserving the city's identity.

\footnotetext{
118 ŠKRINÁROVÁ, A.: Aplikácia rôznych prístupov k obnove mestských opevnení na Slovensku. In: Grant Journal, 2014, p. 63.

119 ZHOU 2019 (see in note 102), p. 11.
}

\footnotetext{
${ }^{120}$ BRUCE - CREIGHTON 2006 (see in note 3), p. 15.

${ }^{121}$ KRAJNIK - PETROVIĆ KRAJNIK 2019 (see in note 34), p. 419.

${ }^{122}$ BREZOVEC - BRUCE 2009 (see in note 61), p. 102.
} 


\title{
Beyond Defence: City Fortifications and Urban Identity in Levoča
}

\author{
Résumé
}

In conclusion, there is no doubt that the fortified city of Levoča has a distinctive urban identity, which has been created and partially preserved thanks to its fortification complex. As it has been argued, the changing function of the fortifications has allowed the public to consume and experience the walls in different ways throughout the history. The new function of city walls, together with the tangible and intangible ideas they represent are important sources of urban identity, since they embody a symbol that commemorates the past. Despite the fact that the fortification system no longer defends the town physically, it acts as a historical monument that preserves its unique character.

In addition to the changing functions of the city walls, it was also the identity of walled towns which has changed over centuries. The walled town of Levoča has transformed from being a free royal fortified town, as seen in the vedute, to a European "gem city". Thus, the fortification system, can in addition to acting as a symbol, be considered as a brand of the town. For the unique urban identity of the town to survive, the coexistence of both concepts is essential. Additionally, adequate approach towards conservation and preservation of city fortifications is essential in order to preserve the urban identity and the town's image.

Overall, the city walls of Levoča have not only had a great impact on the city's urban identity, but also on the lives of the urban dwellers, as well as tourists. People pass by these walled structures every day and perhaps without realising, they feel safe inside of them. Since they form an inseparable part of the town, urbanistically, but also symbolically, they offer a number of ways in which such architectural structures can be consumed and experienced. Finally, after years of denying them as cultural heritage, the public has found new ways of consuming these architectural structures by allocating them new recreational functions. Their preservation and new use allow the public to accept their history and value them as historical monuments and symbols of civic pride in the present. City walls not only changed the identity of walled towns, but above all they became a symbol and a brand of the city and act as a way of preserving the distinctive urban identity of the town in the $21^{\text {st }}$ century. As it has been argued, "Almost as though cities were like people, with distinctive personalities". ${ }^{123}$

Martina Mrázová, B.A. Pri prameni 6 SK-054 01 Levoča e-mail: mrazova.martina@hotmail.com

\footnotetext{
${ }^{123}$ BELL, D. A. - DE-SHALIT, A.: The Spirit of Cities: Why the Identity of a City Matters in a Global Age. Princeton 2011, p. 4.
} 